\title{
Revisiting the Architectural Message as Social Communication
}

\section{Lidiya Ingnatyevna Kirsanova}

\author{
Vladivostok State University of Economics and Service
}

Email: kafedra_tgp@mail.ru

\section{Doi:10.5901/mjss.2015.v6n3s4p59}

\begin{abstract}
The identity of the people is an unfinished process, the content of which is changing, is being revised in the era of. A special role in the justification of the identity of the people belongs to myths- poiesis, i.e. the forms of the collective unconscious, derived from the sphere of no-conceived, from not reflexive experience of ethnicity, nation. In modern times the semantic tension tests the identity of the Slavic peoples - Ukrainians, Russians, and the decor of strife leads almost to the rupture of their historical unity. The author raises the question of whether the idea of self-grounding of the people as the ethical, political, ideological goals-societies (West, Russia, Ukraine, etc.) will be saved in today's globalized world. The role of policy of states that change their principles - freedom, equality rights, the observance of the principles of international law and replaced it with the rhetoric of the struggle for power should be noted. In view of the principle of irresponsibility of the state that citizens take responsibility for the future of the people, choosing at the same time not rational foundation of a stability of society, and mythological elements (language, history, tradition, ritual).
\end{abstract}

Keywords: Group entity situation, Identity of the people, collective unconscious, myth, poiesis.

\section{Introduction}

Today, all attempts to speak, to write, to think about Ukraine, somehow affect Russia. This affectness only means that Russia and Ukraine are the same, just a little bit different. Everything seems to be the same thing: history, language, songs, myths, but a little bit different. Here is an analogy: famous Indian parable about the impossibility of "between nirvana and our world to detect even a very small difference". Difference of the different from the same occurs in moments of worried presence, when certain thing - people, wondered about what it is, how it is what it is. At first that difference within the same remains subtle, this the same seems almost inaudible, it is difficult to understand as experienced (affects of identity exist precisely as affects - anger, hatred, suspicion, but not as something meaningful), reflection at all turned to be deferred. The essence of this original elusive offset is in affectness, in the movement to things of existence as a whole, in the direction to the whole as such, which is called the people (Riker, P.1985).

The aim of the study is the attempt to distinguish the mimesis of the people and its logo. The objective contradiction is that the content of mimesis is the emotional experience of the history of the nation, it includes mifos and biopoesis, and the logo is focused on the interaction of rational structures of consciousness - thinking, its ability for abstraction and idealization, the formulation of the universal in the form of ideas, concepts. The author argues that mythopoesis creates a form of horizontal self-grounding of joint being, while the logo builds a hierarchy of those who speak in its name - the state, the law, politics, elites.

Objectives of the study: to specify the contradiction between mythopoesis and logo of the people on the example of mass protest events, Maidan, for example.

- To analyze existing in philosophical and political literature theoretical concepts of the national spirit. Mythopoesis constitutes centrifugal tendencies of identification of the people, leads to chaos in the political and public life, logo regulates and hierarchytypes the Genesis of universal in forms of outlook and ideology.

- To evaluate existing in modern philosophy trends: the German-speaking authors (Habermas, J. 2006) prefer to discuss the idea of the universal, that "the arche", which is the people in the context of the classical notion of the spirit of the people. French-speaking authors prefer to discuss the problems of "rhizome" community, where interactions are reduced to random intersection of anonymous to each other actors, indifferent singularities (Deleuze, G., Guattari, F. 2004).

- To substantiate the author's position regarding the necessity to preserve the notion of "national spirit" as intelligible concept of social philosophy, philosophical anthropology, political philosophy.

- To show that joint being as horizontal universality, based on the forms of suggestion - the myth, the poetics of 
myths, the ritual undergoes through several phases in its self-justification - chaos of protest consciousness; the rationale of people's life as an area of the country; the restriction of self-existent nation from external forms of identification methods of contiguity or rejection.

\section{Literature Review}

Rationale and self-grounding of the people as some kind of "arche" social has a long historical and philosophical tradition. Martin Heidegger in the article "the Rationale of the German University" in 1931, taking the position of the rector suggested to consider the University as universal as that which gives justification to the German people (Bourdieu, P. 1991). He defined the Germans as a "nation of knowledge", labour and war.

"Community" of singularities is a society without-common. Jean-Luc Nancy in the work of "Being singular plural" considered the modern society as a community of singularities as determinate being (Nancy, J-L. 2000). Community of performance, exposing of joint existence as present, foreseeable, forms a surface of social without the possibility of secrecy, human uniqueness, etc.

Invaluable assistance in understanding the crisis of identity of the people had a work of modern Western thinkers, because Western society much earlier faced a society without-common, strife, war of "all against all".

Italian philosopher and theologian G. Agamben in his book "Homo Sacer.Sovereign power and bare life" diagnosed the appearance in the Western European world of some communities, which cannot claim to be a political being, their fate is to remain unity of "zoe", i.e. a simple biological mass (immigrants, prisoners, etc.) (Agamben, G. 1985). The author used the difference of the people as a political being and as a form of "zoe" in order to analyze the risks of people neglecting self-identification or putted in a situation of a ban on identity.

German philosopher J. Habermas in the political works of recent years regarded the situation of the Western world as the split of the West, as the field of the conflict of interaction of the nations, where mutual claims against each other can not be satisfied in a society of tolerance, but continue to exist as hidden, suppressed motives and desires of the peoples spirit. In detail he focused on the analysis the conflict of Germany and Poland (Habermas, J. 2006).

Important methodological quality is the view of Paul Riker on the fate of peoples, nations, ethnic groups, societies. He argues that the history of the people exists in the form of a story, the characteristic is the title of his book in two volumes: "Time and narrative". In the history remain peoples of Words and Books (Riker, P. 1985). From that follows that the peoples of epics, legends, and literature have a chance to justify and preserve their identity.

Ken Wilber wrote about the forms of the collective unconscious in its function of extension of self-conscious spirit. The psychologist claims that mythopoesis gives epic scope to the individual life, and the connection to the transpersonal energies saves a person from anxiety and fear. It should be noted that mythopoesis does not only increase the excitement, but also provokes obsession (Wilber, K. 1980).

Slovenian philosopher S. Zizek has thematize the problem of joint being by returning of the concept of ideology.He considred the re-ideologization of the Western world through the prism of "cynical" subject of ideology, which replaced the ethical subject of ideology. Zizek regards ideological positions of Stalin and Bukharin as the difference of cynical and conscientious subjects (Zizek, S. 2008). Outlook, mythopoesis, beliefs, ritualism as subjective forms of life are the elements of ideology, but they relate to its mimesis, not the logo.

To solve these tasks, the author relied on the methodology of structuralism and postructuralism. Structuralistic methodology allowed to identify in mythopoesis the mental units of analytics and their functions in the context of that whole which is called the people's spirit. The analyst does not copy the actual process of self-identification of joint life, but gives him a mental picture. Understanding of structural units of mythopoesis and its functions allowed to formulate the conclusion of the gathering of the people in the plane of the horizontal interactions from the center to the periphery. The periphery of the people is everywhere, but there is no center.

Poststructuralist methodology allowed to identify several points of identification, from which the actors are talking, i.e. the right to speech belongs to a variety of stakeholders - students, youth, politicians, military, radicals, women, pensioners, etc. The subjects of the speech dismember "clean" structure analysts, blur the research field, because their speaking is in the nature of "strife", a bitter dispute, but not dialogue.

\section{Results and Discussions}

In a normal world, this movement to matter in general remains inconspicuous, not empirically perceived, mentally not reproducible as concepts, ideas. Due to the automaticity of everyday life, which includes ways to organize the household, hospitality, language, landscape, communication and so on., people don't think about what is the people, because it 
already exists as something that somehow is present. In moments of crisis, the source of which can be the change of religion (paganism-Christianity), change of place of location of people (truncation or an increase in the borders), the inclusion of a whole of the people, and foreign elements (pressure immigration factors), ideological totality (Nazism, for example), the radicalization of relations "us" - "them", the formation of the image of "the enemy", etc. People have always exist, but it needs to find himself, it needs to define itself through the soil, blood, language, mythopoesis (Maffesoli, M. 1991). People "lack" itself as determinate being, as the content of everything that it can present itself as self-grounding in the forms of determinate being, to sit comfortably in it. The people is the source of identity, but from time to time it is necessary to it to constitute itself. At the point of crisis is implemented the strategy formulation "under the question" considereing the affestness by that matter, which is the people. Asking about the general that is the people means the failing in Genesis, in non-reasoning, which ontically is experienced as "something out of sorts", as a not-own Genesis, as anxiety and fear. A special place in attempts to self-determination of the people belongs to what is called "being-togetherwith". Joint Genesis can be forced in the form of a law (Declaration of the rights...), States (USSR, for example), ideology (Islamic state) or voluntary co-participation, the Commonwealth of free men (the beginning of the Maidan and was such an attempt, which caused the sympathy of many Nations). A special place in attempts of self-determination of the people belongs to what is called "Genesis-together-with". Joint Genesis can be forced in the form of a law (Declaration of the rights...), States (USSR, for example), ideology (Islamic state) or voluntary co-participation, the Commonwealth of free men (the beginning of the Maidan was such an attempt, which caused the sympathy of many nations). The transition from forced universality, the violence of which is compounded by the co-existence within the same national borders with othercommonalities with other sources of identification, to free and voluntary universality (like any strategy of liberation) in inevitable connection of risk factors. If in forced co-existence man is not attached to the universal in the form of freedom, it means he does not have a cut in that general, does not have business, fitness, does not belong to the substance of that case, which the state is (according to Rousseau, is not involved in the "Social contract"), does not determine his own destiny, so the people can easily forgiven with the state, law, and goes from vertical to horizontal dispensation of itself (direct arming of the people). Therefore clear is that indiscretion and even frivolity with which Ukraine gave up with its statehood, law, law in General, with any legitimacy. Originally freedom exists in the form of nothingness, emptiness seduces with the opportunity to write on it what you want-meanings. That is why in Ukraine made their ways a variety of commentators of meanings from the extreme right (radical sector) to the extreme left (anarchism in the form of a slogan: "supermarkets without sellers"). When some randomness exists, contingency in joint existence, the people needs knowledge of that, on the basis on which individual actors can participate in the new forms of universality. The people in the form of zoe, "naked life" must become the people of the policy or policies (Agamben, 1985).

The same, but a bit different we are experiencing in Russia: we are not in the way to a new(?) identity, do not put under the"question" being of that whole that we are - the Russian people. That is why we are balanced, calm and peaceful on the background of the anti-sanctions of America and the West, the fall of the ruble exchange rate to the dollar, increasing obsession of "Ukrainians", etc. We have not suffered the "storm and stress "of unfinished identity, which calls into question the very existence of the Ukrainian nation, which was formed as "the gift", or as violence. The stay "in the storm", on draughts of history is very risky. Weather something great (world Ukraine, European Ukraine) or a random, empty, unfounded will born from attempts of self-grounding? This is the choice that Ukraine are to make, and it is not alone, this applies to Poland, Germany, Hungary, Serbia and many from among the "Western" Nations (change in selfidentity: Eastern Europe became Euro-West because of membership in the European Union, concluded the risks of Serbs, Slovenes, poles, etc., Germany still bears the scars of a special "middle way" in relations with Europe (Habermas, J. 1983).

At existence of any problems with the self-grounding of the people, it makes sense to turn to history. If the birthplace of Western Nations is Greece, logical is the passage to the sources of self-identity of the inhabitants of the Greek city-polises. It is known that the Athenian freedom is determined not by the ability to work, the formation of things from nature ("the Cup from clay - famous system of 4 reasons according to Aristotle), not the amount of owned land or wealth, but the number of leisure. Plato, like Aristotle, believed the work being not worthy of a free man. Leisure, idleness, and nothing doing the Athenians put higher the labor for ontological reasons. Firstly, because any activity on the treatment of nature and turning it into a thing to share, sales, profit and so on. generates errors or defects of the incarnation. (Heidegger, M. 1996). According to Plato the real thing and its eidos are never the same, even at the essential mimesis: the ugly bowl differs from beautiful one in essence, their existence in both cases remains defective, but the only in measure of possible coincidence. The thing squeezes to eidos either constitutively or at random, but any fall in the facticity of present being remains defective. Labor as any product produces essential things (skills), and some ugly things. Ontically it is experienced as frustration - by freedom, democracy, arbitrariness, etc. Second ontological imperfection lies in the very structure of being preoccupied: the willingness to otherness, the ability to be different marks a 
man as a "being - all - possibilities", pushing of themselves beyond any factual. Goal-setting as that, for what exists in the mode of waiting for a possible future, that faces the facticity of the life-world, and therefore never can be implemented that ontically is experienced as stress of assumed otherwise-existence (the freedom of other is released from the worries of being, from which arise under the authority of these other, violence and manipulation) or escape from the institution of the new government (frustration, impotence).

If "self-care" was refined technique of life of the privileged strata of the Athenian aristocracy, the meaning of life for the elite to spiritual guidance (Plato believed that government must be ruled by the philosophers), from the Pythagoreans to the Stoics, the pleasure from oneself, narcissism, transpersonal extension of the well known forms of national, grassroots culture, such as the festivals, carnivals, processions, mass rituals, etc. Thus, the changing of ethical characters, the reproach of power, the production of "last" (bottom) at the place of "first" is not some sort of "dislocation", the defect of transpersonal experience (areal, "Maidan" of residence), but the action according to the merits of this event (transpersonal expands the boundaries of its subject by connecting mythological energies), and therefore it is necessary and natural (Wilber, K. 1980). To demolish the monuments of the former government (to destroy the monument to Lenin, for example) and lay flowers to others, reviled before - Stepan Bender, it only marks the turning "top" and "bottom", which marked all the nascent beginnings of a new identity of the people. J. Ranciere noticed that at horizontal identity the "arche" (the people) speaks on behalf of tradition, custom, myth (Ranciere, J. 1995). The mythology of the holiday and idleness reactivates in the collective unconscious some of the "ethnographic" nostalgic "slices of life", about which always dream of the people, lured by "overeated", "fat" elites (poetic expression of this sentiment is the tale of A. Tolstoy "Three fat men"). The ritual - who do not jump is the "Moskal", unconsciously "crowded" (a word of Pavel Florensky) from shamanism "includes" the experience of mythological, poetic, beautiful. Identification with a wonderful (keenness on miracle: the transformation of Ukraine into Europe) restores communication with myths-poiesis from "Evenings on a farm near Dikanka" (humanistic myth) to Viy (terrorist myth: the inability to properly read and speak is in danger of death). From the point of view of mythopoesis, Yatsenyuk, who studied English at Dianetics - Americans - the right guy, and Donetsk miners who do not wish to learn Ukrainian - must be killed. Zaporizhian Sich (the naming of the Ukrainian Parliament, the Rada refers to the dispensation of the Cossack world) is given a mythological function: there is a possibility of a different hierarchy of power relations- the change of the power from vertical to its horizontal. The Maidan is the model of power in which the periphery is everywhere, and the center is nowhere, i.e. the distribution of power relations is carried out according to the centrifugal principle. This should be attached with recovery of mythological image of "Kievan Rus", a romantic glorification of acts of Princess Olga, all the shards of the myths that were thrown into discussion in the field of the Maidan.

Without reliance on the myth can not be any mass movement (mystic of "soil and blood" was the basis of selfgrounding of the German people, the correct reading of the Torah is the bond of the Jewish people, etc.).

From the point of view of estethica, interesting is the speech of M. Heidegger, "the self-assertion of the German University", spoken in Freiburg on 27 may 1933. Its content goes beyond the themes of self-grounding of German University, it is about much larger and important: Heidegger argues that the German nation is a nation of knowledge, the essence of which is mated with will to knowledge, employment stress and the ability to withstand this force in terms of "strife" - defense and war. German thinker argues that self-grounding of the German people is not complete: "the Greatness of the beginning is not yet come. The beginning is still existing. It is not behind us as a once happening, but appears to us." Therefore, under the questioning is all the contents of the General-historical existence of the German people: "nature, history, language, people, custom, state; poetic saying, thinking, believing, sickness, madness, death, law, economy, technology" (Bourdieu, P. 1991). Universal, so is the "unknown" being that creates the world of deepest and extreme danger. "Because the spirit of the people is not just empty words game, not the content of not associated imagination, not boundless race of rational preparation and, especially, not the world-mind, but the determination of the will and expertise in mastering the universal essence" (Bourdieu, P. 1991). Heidegger, trying to save people from unbearable anxiety (!) to be abandoned in nothing, from the "failure in Genesis" proposes to rely on some knowledge, as if it exists, and is not coming, that the people could submit and surrender itself. On what can one relay? The myth of soil and blood, in other words, origin and birth, one should to expose onerself to a certain anamnesis of his past as possible away from standing from the present that should be presented to oneself. How to deconstruct, how to rewrite, to reinterpret their past?

Impulse, passion and even stiffness that is the content of the concept, introduced by Heidegger - determination. "Everything great is in tempest" - Heidegger finishes his rectorial speech with a quote from Plato. If the call to "distribution" (Storm?) was only result of individual temperament, things would be much (Motroschilowa, N. 1991). Personal obsession with something (ancient Germanic spirit) or someone (Fuhrer) does not have such historical proportions, which it acquires when connecting myths-poetic energies of the collective unconscious. Further, the fate of 
the German people was defined as joint fate, co-thrownness, realization of community. Rector (chief, leader, providing the path to slave) turns to be the person who are moving by the force of the shocks of his(!) Daseina. At this point, it is necessary to distinguish existentioning as a fact of personal choice, and joining to the collective unconscious, which minimizes the personality. From this it follows that a significant difference of personal leading from anyone who is a gun or a conductor of the transpersonal. Heidegger certainly belongs to those who staying in existential anxiety, leads directs, points the way, because of this anxiety, and even despair, and has the courage to withstand (Heidegger's Nazism lead impenitence). There is another "leading" cynical manipulation of "mass", where the leader do not differ from any in the parameters of the mind or conscience

As in the ancient tradition, and in German intelligence, there are, at least, the possibility of two strategies of the identification of the people. One of them is based on collective identity or mystical type (soil, blood, origin, the birth of the "third Reich") or in the form of a plebiscite, when to commonness come through participation in voting, culminating in the creation of community, of being-together in the form of the polis as the policy ("the social contract", "universal trading state" I. Fichte, "European world" I. Kant etc.) Unlike collective, individual identity means that eksistentioning individual on bases of his solitary solutions (based on "my own" world) takes responsibility for what he is - the Greek, Roman, German, Russian, etc.

Collective and individual identity are heterogeneous, sometimes, disparate entities. The nation as a concrete universal is necessary in order to seal a mixed identity in whole, to ensure such picking up of past that proves its resolve in the future to be in a certain way. Namely through the spirit the people settles in place, thereby abides in the area. The territory can not be the bond of the people. What is the point of keeping boundaries when national spirit is weakened, and conversely the power of the people is attracting others, that's why territorial expansion takes the form of organic growth.

Mythopoesis of Maidan - strangely acceptable world that blends everything: from reliance on warlords, who are engaged in the war, and agriculture - to the Ukrainian feminists. Zaporizhian Sich is a horizontal agricultural settlement of the ethnic group that serves the purposes of defence, carrying out raids on neighbors for the purpose of enrichment, as well as the distribution of land for processing and cattle, ruled by elected atamans etc. Myths-poiesis includes shamanic ritual in the form of hours of "bobbing" for the purpose of maintaining emotional intensity of the action. A special word should be said about the Ukrainian feminist, mentioning the radical wing of this movement - the group "Femen". Namely they noted a "bare" attack on Putin, trying to oppose bare existence, life as zoe, to the society of the spectacle, staging and manipulation (Nancy, J-L. 2000). Mythopoesis is kept by the energy of dissipation, first, because it relies on being-inpieces", into fragments of different myths, and therefore nothing could gather, its strength lies in the periphery, the capture of a large number of friends and foes. Namely at this moment the percept "global Ukraine" was spread among protestants. Confirmation of the absence of a center of mythopoesis we find in the figures-the simulators - from aglossate Klitschko to dull Yatsenyuk. Secondly, any myth aspires to be universal: in the beginning of independence Ukraine was willing to be the Worldwide Ukraine to reveal to all the peoples the sample of radical freedom, taking from the origins of consumer communism ("to each according to his needs" - in stores without sellers) to the restoration of Kievan Rus, where Russia will be part of Ukraine. It should be noted that immediately followed upon the elections of the Rada the transformation of the universal myth, its collapse was found in the way of naming the neoformation of thebstate Euroukrain, narrowing of the mythopoetic horizon of the identification evidences of the greater adequacy of the elites (the decision of the Parliament), rather than the masses.

The energy of mythopoesis, although is saving from anxiety and fear, so that outputs beyond the determinate being and every factuality (at this point with the threat of winter, rising prices and so on can be neglected) that is ontically experienced as euphoria and obsession, but being a dispersion cannot hold universally in the form of duration. Maidan quickly ended. The initial openness of the Maidan has exhausted itself, its orientation to the future in the form of the utopia project (Ukraine is an independent nation state, where all three concepts belong to the sphere of imagination, which is defined by Heidegger as the modus of the "presence of absence") demanded the self-isolation of that concrete universal, how feel themselves Ukrainian residents. Self-isolation is the core of the centering of the space, but not time, commonness on the basis of soil, blood, language. Centripetal tendencies prevailed over centrifugal. The bet was made on the Ukrainian language, the rejection of bilingualism. Attempts were made to make Ukraine a certain ethnographic "thing" : a closed in space boundaries, locked in one language, focusing on defense and war ("the nation state is a rather shaky temporary balance between the status of some ethnic Stuff - patriotism, nationalism, and so on are the universal function of the market" (Zizek, S. 2008). The consciousness of timing, being-to-end is not only the fate of the individual, but also of the Nations, the peoples, the space provides stability, reduces anxiety and fear, so it makes sense to create and maintain the Empire (Rome, Moscow). Mythologically safe House and the surrounding domesticity was always preferable Path (a metaphor for the time), forthcoming path-the road is always a cause for concern. This is confirmed by specialists psychiastrist: defect of spatial orientation is more severe neurosis than disorientation in time, which confirms, 
for example, the psychoanalyst Medard Boss (Heidegger, M. 2006). Time creates anxiety, a space free from the trouble that provides stability. The oblivion of the past, the lack of history affects people less than when the body loses organs" change of boundaries: it is such a painful reaction of Ukrainians to the possible rejection of the Crimea.

Many today in Ukraine think ("seemity", as known consoles, but is cheating) that from ethnic folk forms of spiritland, kinship language as from graft will born something whole-Ukrainian, that the desired joint being-with-others, which was the purpose of the Maidan. Mythopoesis of "dispersion" and spreading is rapidly exhausted, the reality has come into its own, which is subordinated to the need to build a national state, which causes a lot of difficulties. An anxiety before "tinity" is increasing: ahead are looming threat of loss of access to hydrocarbons, inflation, life "in debt", the domestic political struggle of elites, the awakening of the West and so on.

Let's try to understand whose interests in the West, is contradicted the elected by Ukraine's self-identification based on "ethnographic thing". It is known that M. Heidegger believed that the thing, understood according to Aristotle, true, essential mimesis, protection from anxiety before tinity. The thing is something produced, hand made, derived to being by a master, and therefore understandable and expensive, the near future, which involves all global communication - nature and the cosmos, the gods and mortals. The manufacture of things means the situation that it (a thing) one way or another affects everyone, obviously applies to everyone in the nation, this is what can be broadcast to argue. "Ethnographic" thing as not some self-isolated specialness (Ukraine as a national state) involves placing in the politics of the West, formed on the basis of a particular identity, on what is called the universal appeal of capital and information. Capital and information transcendent across the borders of nation sates, fuses their population in a single community of consumers of the same. Transnational corporations require universal openness of borders, and therefore, their policy is to prevent any kind of close contact and self-madeness, any people is not allowed to do something in their own way, neither the Scots nor the Catalans, neither Basque nor the Greeks. Cultural analogue of the universality of capital and information is multiculturalism - cultural exchange of rarities, useefficiency remnants of ethnicities, nationalities and the peoples (Zizek, S. 2008).

So, the new alarm and danger ahead for Ukraine: "ethnographic thing" as a pattern for the allocation of people based on nationalism, patriotism, the only language and so on., still being formed, is already an anachronism. Any national state, in which there is real ethnic tradition, prevents global circulation of capital. Today's Euro-America is the hegemony of the global market, multiculturalists tolerance, loyalty to claims such as: "equality-freedom-democracy". Contemporary philosopher S. Zizek, of Slovenian origin, affected by the pain of losing national identity, writes: "Global capitalism as cuts the umbilical cord connecting it with his mother-nation, and refers to their country of origin to another territory, that need to colonize" (Zizek, S. 2008). Edward Said warned that the external and internal colonization should be distinguished (Said, E. W. 1978). The USA Department of state - this is not America, it is rather a monster, cut off from "all" roots (from the Declaration of the rights...) and identities in favor of the Ministry of globalization and multiculturalism. The Department of state as monstrous formation together with multinational companies and international banks colonized his people, as all the others. It also successfully performs the external colonization organizes the "color" revolutions, Ukraine got the color orange, slips and even physically destroys the leaders of nation states (Guatemala, Panama, Iraq, Syria, Lebanon,etc.), distributes and supports until very unstable lifestyles and community (a variety of "man-made" group of Westerners, feminists, gays, paramilitary, fascist groups, etc.) in order to multiplex the generality of the people, to calm them down into smaller groups and to oppose each other. Multiculturalism is clearing space of concrete universality, frees people from the emotional and moral attachment to the nation as its man-made cause, creates "empty" space of the universal, in which inscribes its own meanings. Ukraine doesn't say that the West talks about Ukraine in their own language, making clear to themselves the events that occur on the Eastern edge of Europe. The right to speech in their own name withheld based on mythopoeia of people - tradition, tradition, tales, epics, etc. To give your text into the hands of "unknown" kind of interpreters means to lose power over past and future of the people (Derrida, J. 1978).

The whole of nation is divided: many Ukrainians are convinced that capitalism is the best form of life, I wish that it was saved, at least as their own imaginary. Elites and upper middle class hope to have time to take advantage of Western rights and freedoms (visa-free entry, education, work, etc.). They despise the "simple" people "europes" (Ukrainian patriots) called the "quilted jackets" (residents of Donbas) for that they are supposedly not able to break away from his community and language (Russian) identity. The struggle between these "two" peoples: on the one hand, part of those who are focused on the Western vector of development and those who wish to be defined through language, kinship, territory, will continue, and the degree of hardening increases because as the argument of the right side began to use tanks.

Coming danger and a surge of anxiety and fear are expected due to the fact that multiculturalists tolerance does not extend to the recognition of Ukraine as a special "ethnographic things." The centration of this kind of identity is based on the relevance, soil, kinship, language, nationalism and militarism, which inevitably leads to self-isolation. On the other 
hand, Ukraine signed the "colonization", the life of the debt, the rearmament of the army for NATO, the introduction of a foreign government Ministers, thereby de facto already refused national identity.

\section{Conclusion}

Self-grounding of the people (Ukrainian, Russian, Polish, German, etc.) cannot be completed because in history there are crises of identity caused by the split of the social totality - war political and ideological conflicts, it makes the public opinion leaders, ideologues, politicians to return to the search of items of "arche".

Particular importance in shaping the identity of the people belongs to the forms of the collective unconscious, to archetypes, they have to be taken from mythopoesis - myths, epics, tales, historical tales, to give them a new modern interpretation. The work of philosophical reflection is in that in the past of people will be possible once to see the forms of life of the people in the present (Maidan, Bolotnaya, etc).

Self-grounding of the people allows it to move from a forced co-existence, when the coercion is exercised by "externated" entity (state ideology) to the free and voluntary forms of community.

\section{References}

Agamben, G. (1985). Homo Sacer: Sovereign Power and Bare Life. In Europe. pp. 249.

Bourdieu, P. (1991). The politicak Ontologi of Martin Heidegger. Polity. pp. 282.

Derrida, J. (1978). The writing and differences. Chicago: University of Chicago Press. pp. 495.

Deleuze, G. \& Guattari F. (2004). Anti-Oedipus of Capitalism and Schizophrenia. London and New York:Continuum, pp.432.

Foucault, M. (1986). The care of the self: The History of Sexuality, Vol. III Harmondsworth: Penguin. pp. 447.

Habermas, J. (1983). Philosophical-Political Profiles. Theory, Culture s society. Vol. 7. pp. 368.

Habermas, J. (2006). The Pivided West. ISBN 9780745635194. pp.192.

Heidegger, M. (1996). Being and Time. Albany: State University of York Press. pp. 447.

Heidegger, M. (2006). Zollikoner seminare. Vittorio Klostermann Frankfurt am Main. pp. 406.

Maffesoli, M. (1991). Enchantment of the world or divine social. M.: Progress.pp. 315

Motroschilowa, N. (1991). Philosophy of M. Heidegger and modern. M.: Nauka. pp. 253.

Nancy, J-L. (2000). Being Singular Plural. Stanford : Stanford University Press. pp. 272.

Ranciere, J. (1995). On the shores of politics. M.: Prectice. pp. 240.

Riker, P. (1985). Time and narrative. Chicago University of Chicago Press. pp. 496.

Said, E.W. (1978). Orientalism Western conceptions of the Orient. New York:Pantheon Books. pp. 635.

Wilber, K. (1980). Psychologia Perennis: The spectrum of consciousness. Paths beyond ego: the Transpersonal Dimensions in Psychology. Los Angeles. pp.232.

Zizek, S. (2008). The Fragil Absolute: Or, Why is the Christian legacy Worth Fignig For. London: Verso. pp. 178. 
ISSN 2039-2117 (online) ISSN 2039-9340 (print)
Mediterranean Journal of Social Sciences MCSER Publishing, Rome-Italy
Vol 6 No 3 S4 May 2015 